\title{
Edit Zsadányi
}

\section{Impersonal Narration in the Prose of Margit Kaffka, Emma Ritoók and Jolán Földes}

\begin{abstract}
In this paper, I examine the ways in which women writers have contributed to literary modernity, and discuss approaches and rhetoric tropes that are able to convey the peculiarities of femininity. To this purpose, I have chosen to discuss a range of gendered prose poetry methods used by women writers of the first half of the $20^{\text {th }}$ century that articulate the peculiarities of women's identities. Inspired by feminist researchers Griselda Pollock and Rita Felski, I also examine instances and possible interpretations of gendered impersonal narration, such as the rhetoric of enumeration, overlapping cultural and fictional narratives, and the projection of feminine subjectivity onto objects. I also emphasize that we must take into account not only to the voice, language and personality of a character or narrator when examining constructs of their (feminine) self-image, but also other signs emerging elsewhere in the text.
\end{abstract}

In this paper, I examine the ways in which women writers have contributed to literary modernity, and discuss approaches and rhetoric tropes that are able to convey the peculiarities of femininity. To this purpose, I have chosen to discuss a range of gendered prose poetry methods used by women writers of the first half of the $20^{\text {th }}$ century that articulate the peculiarities of women's identities. Inspired by feminist researchers Griselda Pollock and Rita Felski, I also examine instances and possible interpretations of gendered impersonal narration, such as the rhetoric of enumeration, overlapping cultural and fictional narratives, and the projection of feminine subjectivity onto objects. I also emphasize that we must take into account not only to the voice, language and personality of a character or narrator when examining constructs of their (feminine) self-image, but also other signs emerging elsewhere in the text.

Modernization, industrialization, urbanization and demographic growth resulted in fundamental changes, not only in the economy, society, scientific thinking and the arts, but also in other areas of life, such as popular culture, transforming traditional feminine gender roles that had been previously centered on private life. The process of modernization was fueled further in the first half of the $20^{\text {th }}$ century as the emancipation of women, the emergence of women on the labor market, the right to vote and enter higher education, and women graduates choosing intellectual careers unleashed hitherto untapped social energies. I intend to approach these issues from the perspective of narrative poetry, and examine the ways in which women writers have contributed to literary modernity, as well as those approaches and rhetoric tropes that are able to convey the peculiarities of femininity.

In the examined time period, women's literature was largely informed by Hungarian feminism emerging after the Compromise of 1867, which means that certain issues posed by contemporary feminism emerged as literary topics, while others did not - for example, while the education and emancipation of women was an important literary topic, the right to vote, which was another pressing issue of contemporary feminism, was not. Nevertheless, they did highlight problems that could not be approached through political categories, such as the 
internal struggles of women, their spiritual hardships as they strived for emancipation, and the complex games of power and attraction between men and women.

The roots of Hungarian feminism and feminist criticism gaining momentum at the turn of the millennium both date back to women's literature at the beginning of the $20^{\text {th }}$ century. Not only does this allow contemporary feminist research to rediscover forgotten works of feminine modernity, but we may also say that feminist perspectives are themselves informed by these literary works in the process. Unlike the processes experienced in Western Europe, Hungarian women's movements at the beginning of the $20^{\text {th }}$ century have continued well into the present, as similar issues, such as the problems of feminine identity, keep emerging time and time again. To give an example, the emergence of women on the labor market at the beginning of the $20^{\text {th }}$ century was considered one of the driving forces of the economy - and a century later, in a period of economic crisis, the idea that women have resource potential on the labor market has been popularized once again.

As subjects of literary discourse, women writers frequently chose the peculiarities of feminine existence and the issue of feminine identities as the object of their writing, becoming speaking subjects at a historical and intellectual-historical time when the notion of the subject started to become denaturalized. One of the most fundamental changes of the $20^{\text {th }}$ century philosophy was questioning the Cartesian subject, leading to issues such as the decentralization of the subject, the very structure of identity categories, the linguistic, ideological and innate attributes of the subject, and the questioning of self-same personalities. We thus see the formulation of a sense of feminine identity in a period when individuals and individuality were in crisis, and the self-image that sought self-realization and means of discovering and conquering the outside world began to crumble - in other words, feminine individualism gained representation at a time when individualism proper was slowly becoming discredited, and this paper discusses how novels written at the beginning of the $20^{\text {th }}$ century manage to overcome this contradiction. In this period, women's writing already reflects the realization that the self-realizing, world conquering, masculine Cartesian subject is not a viable path for them. Therefore, I analyze rhetorical approaches where discursive positions take precedence over the speaker, and at the same time represent a feminine perspective that channels feminine voices. Furthermore, I also emphasize that when we analyze the constructs of a (feminine) self-image, then we have to take into account not only the voice, language or personality of the character or narrator, but also other signs emerging elsewhere in the text. Classic narratology, for instance, would ask, "Who speaks?" or "Who sees?", but this would not allow us to arrive at a narrative feminine identity that arises from the controversy of central and decentralized subjectivity. Since methods that focus on a character or narrator automatically assume a humanist subjectivity, the approach is unable to uncover the decentralized self-image sought in the text (Fludernik 2001, 619-22).

In the following section, I focus on frequently used poetic tropes and approaches, and the possible reader roles inherent within, which do not pertain specifically to the personalities or discourses of (feminine) narrators and (feminine) characters, but still contribute to the decentralized feminine subjectivity and self-image emerging from the text. I also focus on gendered prose poetry methods used by women writers from the first half of the $20^{\text {th }}$ century, which allow an interpretation that foregrounds a particular feminine identity. 
Towards the end of the 1980's, there was a particular trend in feminist research that sought to extend the interpretation of modern achievements to include the works of women artists. One of the most prominent scholars of this approach was art historian Griselda Pollock, who researched the distinctive features of works by women painters, and criticized exclusionist approaches that promote a single masculine perspective, thereby preventing feminine perspectives from gaining ground. Pollock dedicated several earlier and recent studies to the works of women artists (such as Mary Cassatt, Berthe Morisot, and Dante Gabriella Rosetti), and focused on analyzing features that differed from those of contemporary male artists. In the chapter Spaces of Femininity in her book Vision and Difference: Femininity, Feminism and the Histories of Art (1988), she highlights the differences in the visual thematization of space and the gaze between female and male artists - for example, just like Manet or Degas, Morisot and Cassatt also bring spatial organization into play, but in a different way. Morisot's works, for instance, often operate with two spatial systems or two separate spaces with strongly marked boundaries (such as a rail along the patio or balcony, a balustrade, a veranda, a shore, a dam, a dike or the edge of a boat), and Pollock interpreted this spatial binary, and the dichotomy of the outside and the confined inside, as a manifestation of gender perspectives. In her reading, this binary space is divided into masculine and feminine, and the isolated, confined and decentralized "central" figure symbolizes the confinement and ostracization of women (Pollock 1988, 62). Pollock also considers the gaze, the scenery, and methods that question the objectification of women as common features in the works of early modern women painters, and presents a very persuasive analysis of Cassatt's painting "At the opera" (1879) in her book (Pollock 1988, 7578).

We must also discuss another feminist critical approach, which positions women's achievements as an important and enriching contribution to modernization, and considers focusing on the ostracization of women to be and oversimplification that also reproduces this ostracizing perspective on a meta-level. One representative of this second approach is Rita Felski, who strived to present a more well-rounded picture of the generally accepted feminist view that, in the age of modernity, women's activities were confined to the private sphere (their family and the home), while men enjoyed access to both these and the public sphere (the workplace, entertainment venues and coffee houses). According to Felski, this dichotomy can be overwritten by presenting a more complex picture, and argues, in reference to research by others (Buci-Glucksmann 1986, 222), that the notion of clearly separated spaces (private as feminine, public as masculine) had already been altered by the fact that thousands of women workers have contributed to mass production in factories. The growth of consumer culture also undermined the boundaries of private and public, as the emergence of supermarkets allowed middle class women to access a new public space where they could move freely without an escort -, and engage in social intercourse. Shop windows also undermined the separation of private and public by virtue of showcasing intimate items of clothing in a public space, while at the same time, mass produced consumer goods entered the private space of homes - and let us not forget that gaining political rights and the right to work and enter high education also aided this conquest of public spaces (Felski 1995, 19-21).

I favor both feminist critical approaches discussed above, as both bring up valid points. My research relates to scholars highlighting ostracization and difference inasmuch as I 
also look at instances of modernist feminine poetics, and call attention to the works of Emma Ritoók, just as Pollock foregrounded the works of Cassatt and Morisot. However, I also incorporate Felski's arguments as I search for possible points of convergence between masculine and feminine modern prose and discuss Ritoók's writing alongside the prose of Margit Kaffka and Dezső Kosztolányi.

With the exception of Kaffka, women writers of the first half of the $20^{\text {th }}$ century including Anna Lesznai, Wanda Tóth, Cecile Tormay, Renée Erdős, Emma Ritoók, Jolán Földes, Irén Gulácsy, Juliánna Zsigray, Laura Dánielné Lengyel, Anna Szederkényi, Sophie Török, Mária Berde, Mária Szabó and Piroska Szenes - have all but vanished into oblivion. An entire generation has been erased from our literary consciousness, despite the fact that they had been acknowledged and praised by their contemporaries, and often mentioned as a group. For example, Nyugat frequently published the writings of Kaffka, Lesznai, Tóth and Sarolta Lányi until 1919, followed by a rapid succession of poems by Török and Piroska Reichard, and several publications by Lola Kosáryné Réz, Laura Dánielné Lengyel and Szenes.

As one of the less celebrated women writers, Ritoók saw the elevation of Kaffka above other women writers as a personal conflict. In one of her letters to Tibor Dénes, she rebuked the critic for calling her a follower of Kaffka, referring to his final statement in his book on Kaffka, "The lifework of Margit Kaffka did not vanish without a trace - we need only think of Spiritual Adventurers by Emma Ritoók, or the works of Dezső Szabó.” Ritoók highlighted not only her precedence, but also her artistic independence when she wrote, "I have often read in literary reviews that Kaffka was the first woman writer to write about the spiritual struggles of modern women that you have also highlighted, and I said nothing, despite the fact that On a Straight Path Alone, Great Coincidence, and even Spiritual Adventurers had tackled this issue sooner than her works did, which is natural, seeing as how I am older, and walked down this path at an earlier time. By 1900, I was attending university, and from 1904 onward, I was visiting universities abroad, and clearly saw those conflicts that have unfolded around me, and which I was also involved in. However, if this is the influence that you refer to, Professor, then I must protest, and take a stand, if not for my precedence, then for my independent literary achievements" (Ritoók n. pag.). Ritoók's complaint was indeed justified - not only did Dénes fail to take Ritoók's earlier works into consideration, but he even stated in the foreword of his book that "Margit Kaffka emerged in Hungarian literature unprecedented, and the 'document feminine' is her legacy" (Dénes 1932, 3).

The women writers and poets emerging in the first half of the $20^{\text {th }}$ century have almost completely vanished from literary history. The very umbrella term 'women writers' denoting the relationship between works and their authors - has disappeared, despite the fact that reviews of that period often mentioned them together, and made the connection between their literary activities and the social processes that altered women's gender roles in society. Of these women writers, Kaffka remains the only one standing - one may even risk the assumption that being isolated from women's issues and her contemporaries was the price she had to pay for her admission to the literary canon. Kaffka's writing now garners more attention, and many papers have been published of her works, but as Zsuzsa Horváth (2010, 3 ) points out, the majority of these papers only discuss Colors and Years, while other parts of her lifework remain unexplored as a lasting result of Kaffka's isolation. 
In an earlier study, I discussed features specific to women's prose in the works of women writers from the first half of the $20^{\text {th }}$ century, and emphasized that what we see is not self-realizing narration, but the expansion of the narrative frame (Zsadányi 2007, 827). Following this logic, and the feminist research of Pollock and Felski, I now examine the instances and possible interpretations inherent in gendered impersonal narration, including the rhetoric of enumeration, overlapping cultural and fictional narratives, and the projection of feminine subjectivity onto objects.

\section{The Trope of Enumeration and Feminine Self-Realization}

Kaffka began her literary career writing poems and short stories, and eventually joined the contemporary literary elite with her novels, of which Colors and Years (1912) is the most well-known today. While the first generation of Nyugat considered her an equal, few remembered her in the decade following her death. Eventually, in the 1980's, László Fülöp would write several studies examining the relationship between psychoanalysis and prose in Kaffka's writing (Fülöp 1987), while György Bodnár analyzed remembrance, time management and the representation of social processes from the 1970's onward (Bodnár 2001). From the 1990's, we also see the emergence of papers that apply feminist critical and psychoanalytic perspectives (Tötösy de Zepetnek 1993; Horváth 1999; Séllei 2001; Nyilasy 2005), and I intend to contribute to this line of work by discussing a lesser known novel by Kaffka.

From Kaffka's novel Two Summers (1916), one may conclude that there is a link between renouncing a goal-oriented historical perspective and the rejection of a unified, selfrealizing self-image.

"Her father, the widowed carpenter, disowned her when she eloped with a mechanic from the village at the age of twenty. She was roughing it for three years, all her children still-born, and then became a housekeeper to a windowed official for twenty crowns and love - when she got to know him, she judged him, as a prudent woman, to be suitable for her, and attached this Károly... With the money, they opened their own washhouse, then lost everything they owned in one year's time, and the rest was consumed by the woman's sickness, having brought with her a malady from the mechanic that prevented her from having any more children." (Kaffka 1916, 3)

Enumeration and juxtaposition are common structuring principles in texts, and often serve to question narrative authority, since the speaker does not create subordinate relations, but merely notes the events, instead of structuring them. Both life-turning and marginal events happen to the female protagonist, which allows both to be juxtaposed, since the character accepts her fate, rather than directs it, and the narrator does no more than describe these events. What we hear is basically the voice of history without a narrator, as conceptualized by Emile Benveniste (206), engaging in impersonal discourse, which foreshadows the intrusion of war into the microcosm of the characters.

It is also important to examine the excerpt above from the perspective of the speaker. In the grammatical sense, it is a narrative statement, as the speaker tells the story of another instead of their own - in other words, we are given a heterodiegetic narrator, to use Genette's 
term from classical narratology (244-45). At closer inspection, rhetorical relations reveal that the character's discourse and way of thinking are permeating the dominant narrative perspective - it is the voice of a person who is aware of her limitations, and lives by a "must survive" principle. This permeation, however, is latent in the rhythm of the enumeration and rhetoric elements, rather than in the vocabulary or semantics.

The direction of permeation is also important - since the narrator does not have insight into characters' thoughts and feelings, we may rule out an insider viewpoint and the discourses associated with it, along with the question of narrative competence. Such categories are linked to discourse from the narrator and towards the character, and in the examined case, I emphasize a reversed direction, where the character's viewpoint permeates the discourse of the narrator.

A similar case can be observed in some of Dezső Kosztolányi's short stories from his late period. Let us examine an excerpt from his short story, Motorboat, at the beginning of which we are presented with a short summary of the character's life from the narrator's perspective.

There is no person in the world who is truly happy, and there never can be. And yet there still is, and can be. I myself happen know someone - even if it's just one person - who is truly happy, perhaps the happiest person in the world.

It is Berci, Berci Weigl.

Berci Weigl is our washerwoman's only son.

I practically watched him grow up. He had been visiting us since he was a little kid, when his mother used to do the washing. He was a pale, plain-looking little boy, always silent, as if he had a secret that he would not share for all the world.

He had little interest in his studies, and slipped from one grade to another in high school without anyone noticing. Then, just as he made the eight grade, the military snatched him up, and took him to the front lines.

He did not get injured or captured, he received no honors - he simply went home safe and sound on the very day he was discharged.

He immediately got married, too, and married - I know not why or how - a bland young lady working as a manicurist. (Kosztolányi n. pag.)

The narrator later enters the short story as a character, and from then on relates his impressions without any insight into Berci Weigl's mind, which results in clearly marked character and character-narrator subjects. The rest of the short story revolves around the family members asking the narrator-character to dissuade Berci from his impossible plans, which he attempts, to no avail. Meanwhile, we see from his perspective how poor the family is, living in an apartment too small for them, and as this unfolds, the characters of Berci and the narrator are sharply contrasted, one a sober, condescending person trying to persuade Berci, and the other, a stubborn man refusing to listen. Nevertheless, at the end of the text, the discourse is altered, and a new narrative voice emerges.

When his children are coughing and crying, he thinks of the fact that he has a motorboat. When he sees his temple going gray, the hair atop his head giving away, and his wife more old, ugly and sour by the day, when they harangue him about having nothing to eat at home, when his mother's waist hurts after washing chores, 
when his grandfather is picking at his colored moles, when he is being bullied by the silent Transylvanian refugee, and embarrassing financial arguments arise from selling cigarettes, he thinks of the fact that he has a motorboat. When others disdain and scorn him, when he has to scribble in the factory in a luster armband, when people constantly remind him that he is nothing and nobody, that he does not count in society, though he can count in his office until he croaks, he thinks of the fact that he has a motorboat, and those who exploit him, ignore him and kick him, do not have a motorboat. When the Danube freezes a good span thick in winter, with a meter of snow on top of that icy skin, when darkness consumes the very pillars of the bridge so that one cannot even see the water that is so wonderful to roam on, he thinks of the fact that nothing lasts forever, and March will see it going again - always and everywhere, he thinks of the fact that he has a motorboat.

I have been watching him for years, and I admire his happiness, for it does not dissipate, but grows more and more. Not even fulfillment could put an end to it. This is why I risked the assumption that Berci Weigl was a happy man, perhaps the happiest person in the world. You do not need much for true happiness, really - just a good obsession, and a good motorboat. (Kosztolányi n. pag.)

In the excerpt above, it is difficult to decide who the actual speaker is - semantically, it is possible that the narrator adopted Berci's vocabulary by using words such as exploit him, ignore him, until he croaks, kick him, they do not have a motorboat - these are the words of an angry, bitter man, and could easily be attributed to Berci. However, it is also a poetic, dynamic and rhythmic text with its own thought-rhythm, as one can feel that it is the obsessive thinking of a maniac, but at the same time, the everyday vocabulary of this obsession and desperation is elevated into an artistic construct. On close inspection, he sees his temple going gray not only rhymes with old, ugly and sour by the day, but also matches it in rhythm, lending charm to these common words of desperation as the female and male tones in the background come together into a single heart beat, and yet the comic effect is undeniable, which also mitigates the painful fact of aging.

The question of otherness is also fore-grounded in both cases as they question the distinction between normal and other. The problem (which has recently resurfaced in theories of subordination) is how the benevolent Western intellectual occupying the normal position can acknowledge otherness without assimilation or condescension. In Motorboat, both attitudes are present - we can see the condescending half reserving its normal position as it bestows second-hand clothing on the other, and also the half that is able to relate, despite themselves, to the obsessed maniac, and let the voice of this other into their own discourse. In the excerpt quoted above, this personal discourse is altered, and its language becomes receptive to the obsessed man's perspective.

It is also important to note that acknowledging the other in the text was not done through conscious concession, but through involuntary identification, as the text suggests that the narrator secretly adopted Berci's point of view to a certain degree, and repeated his obsession despite themselves, showing us that solidarity means liberating and voicing the other inside ourselves, rather than stifling and silencing it until it turns into prejudice.

Another case of impersonal narration is Street of the Fishing Cat by Jolán Földes, the 1936 novel that won first prize in the international novel writing competition issued by Pinker Publishing in London. The award-winning novel was soon translated and published in several 
languages, and sold in the millions across Europe and America, with numerous editions published in several countries. However, at a time when the bestsellers of male novelists like Zsigmond Móricz, László Németh and Áron Tamási only sold in the thousands, contemporary critics did not know how to deal with the unprecedented success of Földes' novel, and soon labeled it insubstantial and superficial (Hegedüs 1989, 198).

Földes was born in 1902, and immigrated to Paris in 1919, where she became a worker, and eventually, a secretary at a film studio. Her other novels were also successful in Europe and America, and after she immigrated to London in 1941, she continued to write under the alias Yolanda Foldes, and later as Yolanda Clarent. Several of her books were also adapted to the big screen - Marlene Dietrich was the star of Golden Earrings (1947), for example.

One of the most pivotal inquiries posed by today's critics is how Street of the Fishing Cat managed to become so successful, since 1989 and 2006 editions of the novel have been just as well received by readers. According to Károly Szakonyi in his prologue to the 1989 edition of the book, this success was due to talented story-telling, and the fact that Földes' simplistic imagery easily engages the reader (8), which is basically the same opinion held by her contemporary critics. However, in the epilogue of the same edition, Géza Hegedüs takes a completely different stance, claiming that the time had come judge the book objectively as an interesting novel of high artistic standard, and a timeless classic of Hungarian literature. He also reiterates, albeit more subtly, the observation that Földes' novel reads like a report, and draws a parallel between her narrative style and the present and past status reports of Knickerbocker, Egon Erwin Kisch, Emil Ludwig, and the war imagery of Remarque and Rodion Markovics, somewhere between epic romantic storytelling and fact-structuring report. After such warm reception, a new edition was published in 2006 (Hegedüs 1989, 197).

The novel ends as one of the characters, Annus, muses on people in exile, saying, "One or two will hold their own on foreign ground. The rest? They shall pass, slowly and without a trace." Looking back, Street of the Fishing Cat can also be read as a literary work resisting this traceless passing by standing as a memento of those long forgotten, and showing us micro histories not to be found in any history book. This way, as the characters speak of well known political events, they also transport them to a completely different textual environment.

Like many others after the First World War, the Barabás family tries to earn an honest living in Paris, and we follow the lives of the three Barabás children (Klári, Jani and Anna) and their parents from the everyday problems of learning a foreign language and finding employment to the difficulties of integration and fighting homesickness. The family is also joined by a former Russian banker, a former Baltic mathematics teacher, and the family of a former Italian diplomat, forming an atmosphere in which these different points of view serve first and foremost to spice up conversation, as their bond is stronger than their differences. They have left their past behind and live in the present, for the present, turning their future into something of a fairy tale that the others can listen to with pleasure and sympathy. This displacement thus creates a unique chronotopos in the novel, wherein social differences fade away, past and present are torn apart, and the notion of being a family extends to these people living in a state of foreignness, in a space between their own culture and the receiving culture. 
What best characterizes Földes' novel is the use of present tense so that the narrator can maintain the illusion of conversation and story-telling. The narrator thus remains close to their characters not only in time, but also in value judgment, as the reports of the characters' daily struggles speak of sympathy, and a close bond. The use of present tense does away with the past, and forces us to concentrate on the here and now, keeping us in a constant state of readiness, because fast paced events (there is something new on every page - somebody going away, somebody showing up, sickness, death, love, and more symptoms of homesickness) constantly keep the readers on their toes. The novel is difficult to put down because it basically requires readers to share every single moment with the characters, who work hard on each and every page, their constant toil continuously felt. We may also understand the use of present tense as a lack of substantial progress in the family's life - although they manage to move to an apartment from the hotel, they lose the fruits of their labor over and over again, returning to poverty and struggling to rise once more. Another interesting feature of the narrative is that constant repetition not only changes the story itself, but also the way it is told - as the narrator keeps repeating constant everyday occurrences, the events fail to adhere to a progressive, goal-oriented structural frame. Therefore, just as in Colors and Years, the iterative structural principles also apply here, and the result is several narrative modes of constant adaptation and continuous renewal written into a meta-structure that is itself based on repetition.

Authors using impersonal narration often experiment with methods that "test their limits", because they introduce new issues to literary discourse. Whereas Kaffka's Colors and Years turns the unliterary into literary, the non-novel into a novel, writing of everyday bickering and stealing the last pennies from the pocket of a sleeping drunkard, so Földes alters the selection of events. In her case, the narrator does not choose events by sampling out the important ones that advance the plot - in other words, elements worthy of literary narration -, but rather gives the illusion of telling every event without discrimination as they unfold. This way, the authority of the narrator is questioned, and the act of storytelling becomes the fiction of the person noting the events, rather than the person that set them into motion.

The characters do not question the causes behind the events, but merely adapt to the current situation, much like the characters in Two Summers. They do not revolt, having no one to revolt against, no tangible source of power to fight, as their lives are shaped by the impersonal factors of history beyond human comprehension. We are thus given a blend of impersonal and personal perspectives - a dual focus, if you will, as we learn of the impersonal narrative of history, the events of the First World War, from an individual's perspective, and this impersonal narration questions both the heroic nature of the self-realizing individual, and the validity of individual decisions. In this light, the grand narratives of historical processes also lose their heroic nature, and merely serve as background information to the foregrounded, thoroughly intense family micro stories.

\section{Cultural and Fictional Narratives}

After a short summary of her life, I will analyze the relationship between the predetermined gender roles for women in culture and the fictional life story of a woman in some of Ritoók's earliest short stories. Ritoók was born in Nagyvárad in 1868, and attended 
university in Budapest, Leipzig and Paris, where she graduated from the Faculty of Liberal Arts, and began working for the Metropolitan Library in Budapest. In 1905, she won a prize with her novel, On a Straight Road Alone, which, along with other earlier writings, explores issues of femininity, and offers a well-rounded, contemporary picture of the changing situation of women. She also translated literary works, and brought Northern literature to the Hungarian public. As for her lifework, it still awaits further scrutiny - recent feminist critics give preference to her earlier prose, while András Lányi holds her philosophic work in high esteem.

Although it is well known that Ritoók was involved with the Sunday Circle (Vasárnapi Kör) and György Lukács, her literary activity is still largely ignored and forgotten. For example, A Blue-stocking by Béla Illés is dedicated to the elderly Ritoók, with a single paragraph summarizing her life - in which only her travels and her first novel merit acknowledgement -, while the rest of her life, according to Illés, is nothing but failures and exclusion from every circle and literary group. "She wrote, she worked, she lived, she had her books published, and did all this in an atmosphere without air and echo, in a cruel spiritual Torricellian vacuum" (Lengyel 1994, 9). András Lengyel, on his part, discusses Emma Ritoók's career in a very thorough and detailed study, following up the most important events and works of her life, such as her entering university education at the age of thirty-two, once new laws enabled women to pursue university degrees. Lengyel also praises her work as a philosopher, but does not consider her literary achievements important (Lengyel 1994, 15-19).

Unlike Lengyel, I am of the opinion that Ritoók's literary activities also merit attention. Take, for example, her short stories in Four Around the Fire (1911), which are seemingly completely different and unrelated - there is no connection between them subjectwise, since they are stories told by people of very different social situations. Nevertheless, the narrative situation between the narrators and readers of Four Around the Fire ties them together all the same - in each case, we get a glimpse of the key moments of the characters' lives, and like in the light of the fire, certain events are illuminated, while others remain in the background. When we gain insight into certain events, we also develop assumptions about the material that is not said or textualized, and the presence of this dark, unspoken content is strongly felt "behind" each illuminated story. The events are also told without any back story, so in theory, each short story could be told around the fire in conversation, as the narrative is not shaped by processes that progress in time, but rather appears to be a linear sequence of scenes that unfold in the present narration, thus giving the illusion of a narrative that progresses in time.

Prewritten social roles and the issue of gender are also present in Ritoók's writing. Of special interest are those parts in which the narrator enters into dialogue with well-known cultural narrative, which basically means that fiction reenacts how fiction builds "reality". For example, in the short story The Final Scene in Hostile World (1913) we see an echo of the archetypal story of animosity between the aging, successful woman and the aspiring young woman. At first glance, we are merely reading a story about the great tragic actress, Eszter Domonkos, competing with the young, talented actress Józsa Simondi. In the story, the older actress retires at the height of her career, and begins a new life by opening an artistic salon. This is where a young, less talented man seizes the opportunity to become a popular writer with her help, and when Domonkos finds out that the man escorts her old rival home, she 
ends her life. It requires several re-readings of this story to detect the dramatic poses and overacted moments of the text that feel as if the characters were behaving according to prewritten roles.

In the story of the two women, there is a hint of an older story that motivates the actions of the actress, and reminds us of such cultural narratives as Sleeping Beauty, in which we see the traditional gender roles of our culture taking shape. However, Domonkosné eventually manages to step out of the grand tale of animosity between women and creates a new discourse by opening her own salon, and being a talented individual, she succeeds in her endeavors. However, a single sentence, objective and devoid of judgment, informs us of the threat to this new and independent world - "Zoltán Újhelyi singled out this salon and this woman to build his future on" (Ritoók 1913, 54). The narrator does not explain what is meant by "build" - only the phrase singled out hints at a darker meaning, and so, even though the narrator's comment is unexplained, the phenomenon is so well-known that no expansion is necessary. Everybody is familiar with the idea of a young, ambition man "building" on an older and respected woman - this cultural narrative is just as well-known and banal as the animosity between the successful older actress and the aspiring younger actress. The sentence is not communicated from the actress' perspective - she is merely the chosen victim, which shows that the women is the one gazed at, rather than the one who gazes, and therefore does not occupy an active position, but one where she is the one who the events happen to. This references a specific feminine fate, as evidenced by the self-explanatory nature of the text and the fact that the phenomenon does not warrant explanation. This statement is also connected to the narrative phenomena highlighted by Benveniste, whereby the story relates itself without attaching to a central subject, narrator or character - it is a narrative statement in which people have no bearing on the outcome of the events happening to them.

The issue of older narratives, the influence of cultural patterns on human action, and the importance of reality-making roles and role-playing also surface in other earlier writings by Ritoók. In Hanna's Dramas (1911), the focal point is the realizing potential of fiction, the scenes of scenes, and the role-play of the characters, which also direct attention to potential roles for the reader. The story is "about" a young lady who longs for a more interesting (life)story than the one she ended up with, saying "And she just had to have such a ridiculously simple, dull and common love story, and bear the acquiescent smiles of the whole party!" (17). In one particular scene of the short story, the scene itself creates emotions, and the situation creates the love story when the young man proposing an offer of marriage on behalf of his friend unwittingly succumbs to the dramatic situation and finds himself in the arms of the lady in question. Even they are unable to comprehend the situation - the drama simply happens to them, and they act out their roles as obedient puppets, rather than active agents of the situation, and only in the jealousy scene, when Hanna utters the proper last words to her husband, does the scene lead to divorce. Hanna's thoughts thus point out the contradictions of forming a feminine identity, and the issues that surround the shaping of feminine subjectivity in the $20^{\text {th }}$ century - "In this eternally monotone, gray life, even tragedies last but a few moments, and come and fade, unprepared, almost without you even knowing, leaving no trace behind."

The notion of people almost automatically adopting roles without knowing means moving away from the idea of a coherent, self-forming and self-realizing, consciously 
controlled subjectivity. The space of feminine subjects is expressed in constant, halfway intentional, situational role-playing, which does not mean the rejection of roles or the search for a "true" feminine self from a choice of social roles, but finding a different role altogether. The reader basically follows Hanna's roles, good or bad, from being a woman in love to a wife cheating on her husband, a divorced woman, and finally, a friend supporting a younger man. This casting lasts to the very end, from the start of her life to the finish, without any stepping out or any hidden feminine backdrop - in fact, the lack of these is virtually unfelt by readers. „And Hanna clearly saw that this was the most interesting, the true drama of her life, unfolding behind the most everyday scene imaginable" (23). Such narrative judgment does not rule out an ironic reading, but we still cannot say that a true femininity, or stepping out, are considered to be lacking, because feminine identity is constituted by previously determined cultural roles - a subjectivity surfacing from the story that goes beyond modernity, and is still relevant today.

In the short story Galeotto, Ritoók focuses on the realizing potential of fiction, and the logic of jealousy comes to be interpreted as a meta-narrative problematizing the issue of representation and what constitutes literature itself. The story is about an older woman marrying a younger man, and harboring jealousy towards her daughter from her first marriage. Although the two young people, the husband and the daughter, feel nothing for each other, the wife's unreasonable jealousy creates uncomfortable tension between them, which suddenly turns into love in a cliché courting scene (looking into each other's eyes as they exchange music sheets). It is not the two young people's love that sparks jealousy - instead, it is jealousy that sparks love between them, transforming the jealousy scene into a linguistic theory debate about the realizing potential of words.

'You are lying... it is true after all... you do love...'

'Silence, don't say it!' whispered the man, grabbing the woman's arm and forcing her onto the sofa. 'Don't say it! The way your jealousy showed what... could be... maybe the spoken word... your own words might do what your madness conjured up.' (Ritoók n. pag.)

As we can see from this excerpt, spoken word becomes reality, and discourse becomes action as the magical power of speech becomes akin to an incantation. In this case, jealousy made the woman see, and she unwittingly saw what the other two did not, thereby pointing out the possibility of love. The ending of the short story also merits closer inspection, as the daughter, Lea, informs Jeney, the husband of her mother, that she would marry another young man.

And she calmly, simply told Jeney that she would marry Vass.

'It is your wish too, is it not?' she asked softly, waiting.

'Yes, Lea, it is my wish too.' He took her hands in his, and she - had he said he wanted her dead - would have obliged him gladly. But he said no such thing. $\mathrm{He}$ simply held onto her hands, and then suddenly embraced her yielding body, and kissing her, he whispered in her hair,

'I want this, too...'

Six weeks later, Lea married, simply, calmly, and unhappily. (Ritoók n. pag.) 
The last sentences of the short story are hauntingly similar to the discourse of Gertrude Stein's Three Lives (1909) with its indifferent, uneventful narration of women's lives. Basically, all statements are objective, albeit with an uncommon word order - multiple adverbs following the predicate -, and the circumstances are described only after a fact had been stated, only to have supplementary statements undermine the previous statement. Take, for example, how the repetition of "simply, calmly" frames Lea's "calm and simple" announcement, and could serve as an overall framework for the text in-between, except for the fact that the frame is imperfect because calm and simple are reversed in the repetition, which could be repetition, emphasis, or even inversion. The framework is further undone by the last word unhappily, which lengthens the frame, reaching beyond the closed structure. The word itself is an addition, a amendment to completely closed whole, thus questioning the unity of the single closed unit - therefore, unhappily undermines, semantically and rhetorically, the narrative voice that sums up the woman's fate with an indifference informed by fate and history. In this light, the "love constructing" nature of the piano scene is foregrounded, because it is not about two people instinctively attracted to one another, but their recognizing themselves in the basic patterns of their culture, and behaving, and even feeling, accordingly.

Rereading the text, we can focus more on cliché elements, and can even read the lines in a way that challenges the narrative viewpoint, because much like the question of fictionality, the idea of love is also a relevant notion that points beyond modernity to the postmodern. We see that love is more than attraction arising between two people - it is the appropriation of inherited cultural behavioral patterns, and the ability to identify with these patterns. Therefore, it is the moment of handing over the fallen music sheet that creates love in this scenario.

As the girl suddenly lowered the music rack, the sheets slipped off with a flat rustle. Jeney reached for them and gave them back. They looked at each other, a long look, and in the last moment, their eyes gleamed with terror.

'Impossible', thought the girl. 'Impossible', reasoned the man... and at that moment, they clearly felt the great, tragic possibility that mad jealousy had alerted them to, and which was now beyond their power to ignore. (Ritoók 1911, 45)

Upon rereading this scene, we may think of many similar scenes from Hungarian and foreign literature alike, making us doubt even great love stories, and allowing us to take an ironic stance towards Jeney's lonely nights when he yearns and thinks of Lea.

He thought of Lea - her figure, her eyes, her hair, first separately, and then of her whole, sweet, lovely youth that enveloped her as naturally as air, and was, by nature, the missing half to his. (Ritoók n. pag.)

Semantically, placing separately after the enumeration of body parts seems superfluous, since the very act of enumeration and foregrounding details allows us to deduce that he thought of them separately. The original Hungarian term, külön-külön, is also a repetition and a statement trope, since it belongs to both adjacent syntagms, and can therefore be understood as an exaggeration or hyperbole. When the enumeration continues, it follows the logic of how 
objects of desire emerge, and separately points out this physical desire, especially when the beauty of youth is also mentioned side by side - which allows us to reinterpret the final parting scene.

In the parting scene, embracing the yielding body, and touching her hair and saying, "I

want this, too..." can also mean physical desire, and this, too can also mean the girl's yielding body, rather than her decision to marry another. Finally, in the last sentence, the repetition of simple and calm denotes an endless stream of marriages without passion or desire, naturalizing them, speaking not only of the irreversible tragedy of a bad decision, but also of the century-old cultural narrative of the relationship between marriage, stifling desires, and women's fate.

\section{Subjectivity Projected Onto Objects}

Coming back to Kaffka's magnum opus Colors and Years, we may wonder what remains with the protagonist throughout her lifetime of losses, and the answer is some old brown furniture and the flowers - "Red hollyhocks, mallows, bleeding hearts, tutsans, resedas, ladies' slippers". These are the things that remained with her throughout life, and offer her a sense of stability in change as objects onto which she can project her personality. She never asks herself the question "Who am I?", which also prevents her from asking "What am I capable of?", because the preprogrammed life pattern of advancing in life through marriage shrouds this possibility. The protagonist's feminine subjectivity is thus projected onto objects - she identifies herself with the flowers, but more importantly, this identification is not with flowers in general, but several kinds of flowers at the same time. In this case, enumeration, a very characteristic trope of Kaffka's literary language, emphasizes the colorfulness and individuality of feminine subjectivity. One evident gesture of the character's identification with the flowers is the enumeration showing her despair upon the death of her husband - "Then, life clashed above my head, hacked me to shreds, made me miserable, tore me from my stem, pushed me out of my place in the world, threw me away, pulled the ground from under me, the shelter from above my head."

Another example of feminine subjectivities that cannot be expressed in words, and must therefore be projected onto objects, is Anna Sweet by Kosztolányi, or the character Erzsi in Ritoók's Quiet Life. When the chimney sweeper asks for Anna Sweet's hand in marriage, he invites her over to their house to show her around, and shows her the room looking to the garden. Anna has no inkling of what awaits her, but as she examines the objects, what causes her to feel joy is perhaps a glimpse of a promising future - we do not know this for certain, of course, as the narration hints at the limits of narrative competence.

There were many things here. Two beds with bed-linen and everything, a couch, a dresser, and a table. Mr. Báthory opened the clothes cabinets, and showed her his first wife's underclothes laying there washed and untouched: six shirts, three petticoats, three night gowns, and a red Himalaya scarf. He spoke to her with much respect and esteem. Anna was immersed in thought, and a sense of languid joy flushed over her. (Kosztolányi 1926, 134) 
Most of the paragraph consists of enumerating objects as we gaze through Mr. Báthory and Anna and take in everything, our new knowledge informed by earlier parts of the text about Anna's meager wardrobe, and the blue print dress always worn by Krisztina. The enumeration thus reveals that Anna's quality of life will change drastically from what she experienced at the Vizy family.

Similarly, when Erzsi, the last descendant of a noble family, now living in poverty, looks at the furniture in Ritoók's Quiet Life, she decides that she shall marry a peasant, an act which will fundamentally alter her identity.

"Suddenly, she stopped at the door - she thought she heard the dry, impatient thump of a walking stick from within. She hastily opened the door, and the room was, of course, empty. And yet she had been hearing that thump by the armchair over and over these days, though that haggard hand was now resting below the ground. How strange this room looks now! It isn't even hers by right, just by pity. The furniture will be good enough for the new house - she will take the armchair, too.

She missed having someone to care for, and she waited gladly for autumn, to be her own mistress again. She wanted a garden with flowers, two cows and lots of small animals." (Ritoók n. pag.)

From the exclamation, How strange this room looks now!, there is a discursive switch to a kind of free indirect speech, where the character's direct thoughts are narrated without marking the narrator's presence ("thought that", "thought", etc.). Exclamations are a feature of free indirect speech, while alignment is that of indirect speech, narrating the thoughts as they are, and following the line of thought gleaned from the character's personality, as if the character had spoken. The only feature reminding us that these thoughts are narrated, rather than quoted, is the use of the third person (hers instead of mine, she will take instead of I will take) - such switches are common in Ritoók's prose, as she allows a glimpse into the character's mind for a few moments, and then distances the readers once again.

From the girl's perspective, her own home becomes alien to her, and when she takes the old furniture to the new house, she basically transports it across cultures by translating, or reinterpreting the furniture, which one could understand as a metonymy of her home, herself and her surroundings. She reinterprets and reformulates her identity, projecting it onto objects, and in this process, the armchair stands out from among the rest, because the formidable grandmother, who guarded the reputation of the Korponay family, can no longer occupy it. However, her memory shall not be left behind because the girl does not want to part with her, being the only person who ever cared for her - thus the objectified memory of the grandmother is transferred to another culture, devalued perhaps, but still enriching her lowly station in life.

The armchair now crosses boundaries the way words cross from one linguistic culture to another, and parts with the world of nobles to cross into the world of peasants, and as a noble relic, it enriches the poor, and thus retains some of its noble identity. The rest of the short story also makes clear that this newly forged feminine identity is difficult to categorize, and remains unexpressed and marked only by objects - she adds a flower garden, two cows and lots of small animals to the furniture and armchair, but all these subtle touches have very little effect on her. In this light, a later sentence, I do not belong here, can also be 
reinterpreted in several ways - this is her proud rejection in response to András Korponay's inquiry, but it can also be seen as an unconscious slip of the tongue, betraying a sense of nobility, and perhaps that is why the man tips his hat to her. However, it can also hint at a feminine voice stuck outside the category that is only able to express its situation through negativity, and can only situate herself by stating where she does not belong.

In Kosztolányi's text, narration is more distant, leaving open the question of whether we see the character from an outside or inside viewpoint with flushed over her, while in Ritoók's case, it is the narrator who steps out and the character's statement disrupts the narration. Whereas Kosztolányi's text marks the boundaries of narrator and narration, clearly leaving the narrator in control of the story, Ritoók's text marks the disruption quite clearly, because she reaches the point of disrupting the narration, and erasing the starting narrative frame.

We may deduce from the examples above that the feminine narrative subject mapped itself in a historical perspective and operated with very relevant notions of the subject as early as the first half of the $20^{\text {th }}$ century. It reaches towards the postmodern horizon with its impersonal narration of women's fate, self-consciousness expressed through objects, and in prewritten roles that have no essential femininity, and contains within itself the realization of linguistic and cultural antecedence.

Translated by Éva Misits. 


\section{Works Cited}

Benveniste, Emile. 1971. Problems in General Linguistics. Miami: U of Miami P.

Bodnár, György. 2001. Kaffka Margit. Budapest: Balassi.

Buci-Glucksmann, Christine. 1986. "Castrophic Utopia: The Feminine as Allegory of the Modern.” Representations 14. X.

Dénes, Tibor. 1932. Kaffka Margit. Pécs-Budapest: Danubia.

Felski, Rita. 1995. The Gender of Modernity. Cambridge: Harvard UP.

Fludernik, Monika. 2001. "New Wine in Old Bottles? Voice, Focalization, and New Writing." New Literary History 32.3: 619-38.

Fülöp, László. 1987. Kaffka Margit. Budapest: Gondolat.

Genette, Gérald. 1980. Narrative Discourse: An Essay in Method. Ithaca: Cornell UP.

Hegedűs, Géza. 1989. "Utószó. Földes Jolán és a halászó macska uccája” (Epilogue. Jolán Földes and the Street of the Fishing Cat). In Földes, Jolán: A halászó macska uccája (Street of the Fishing Cat). Budapest: Pallas. 195-204.

Horváth, Györgyi. 1999. "Női irodalom a magyar századelőn. A női irodalom szerepe Kaffka Margit Színek és évek címü regényének kritikai megítélésében" (Hungarian Women's Literature at the Turn of the Century: The Role of Women's Literature in the Critical Reception of Margit Kaffka's Colors and Years). Sárkányfü 4.4: 54-66.

Horváth, Zsuzsa. 2010. "Az élettörténet mint játékszer". Fikció, narráció és identitás összefüggései Kaffka-regényekben ("Life Story as a Toy": Fiction, Narration and Identity in Kaffka's Novels). Doctoral dissertation manuscript. Budapest: Eötvös Loránd Tudományegyetem.

Illés, Endre. 1979. "Egy kékharisnya" (A Blue Stocking). In Mestereim, barátaim, szerelmeim (My Teachers, my Friends, my Lovers). Budapest: Magvető Kiadó. 360-69.

Kaffka, Margit. 1974. Két nyár. Budapest: Szépirodalmi Kiadó.

Kosztolányi, Dezső. "Motorcsónak" (Motorboat). Online version accessed at: <http://mek.niif.hu/00700/00746/00746.htm\#31>.

Lengyel, András. 1994. “A Vasárnapi Kör »renegátja«. A gondolkodó Ritoók Emmáról” [The »Renegade« of the Sunday Circle: Emma Ritoók as a Philosopher]. In Utak és csapdák. Irodalom- és müvelödéstörténeti tanulmányok (Roads and Traps: Papers in Literature and Cultural History). Budapest: Tekintet Alapítvány. 7-76.

Nyilasy, Balázs. 2005. "Udvarlás, asszonytudomány, erotika Kaffka Margit szépprózai müveiben" (Courtship, Women's Wisdom and Erotica in Margit Kaffka's Literary Prose). Korunk 16.1: 96-102.

Pollock, Griselda. 1988. Vision and Difference: Femininity, Feminism and the Histories of Art. New York: Routledge.

Ritoók, Emma. 1933. Ritoók Emma levelei Dénes Tibornak (Emma Ritoók’s Correspondence with Tibor Dénes). Budapest: Országos Széchenyi Könyvtár Levéltár, 8 November.

Ritoók, Emma. 1913. Ellenséges világ (Hostile World). Budapest: Nyugat.

Ritoók, Emma. 1911. Négyen a tüz körül (Four Around the Fire). Budapest: Politzer Zsigmond és Fia. 
Szakonyi, Károly. 1989. "Előszó” (Prologue). In Földes, Jolán: A halászó macska uccája (Street of the Fishing Cat). Budapest: Pallas. 5-8.

Séllei, Nóra. 2001. "Az asszonyíró és az önéletrajz" (Woman Writer and Autobiography). Tükröm, tükröm... (Mirror, Mirror...) Debrecen: Csokonai. 257-307.

Tötösy de Zepetnek, Steven. 1993. "Kaffka Margit prózája: az irodalmi feminizmus kezdete Magyarországon” (Margit Kaffka's Prose: The Beginning of Literary Feminism in Hungary). Békési, Imre et al. eds. Régi és új peregrináció. Magyarok külföldön, külföldiek Magyarországon (Old and New Peregrinations: Hungarians in Foreign Land, Foreigners in Hungarian Land). Volume 2. Budapest-Szeged: Nemzetközi Magyar Filológiai Társaság Scriptum Kft. 1185-94.

Zsadányi, Edit. 2007. “Kaffka Margit: Irónők a századelőn” (Margit Kaffka: Female Writers at the Turn of the Century). Transl. by: Éva Misits. Mihály Szegedy-Maszák ed. A magyar irodalom történetei I-III. (Stories of Hungarian Literature I-III). Volume II. Budapest:

Gondolat Kiadó. 811-26. 